\title{
Levels of substitution of corn by soybean hulls in high-concentrate diets for finishing beef heifers
}

\section{Níveis de substituição do milho por casca de soja em dietas de alta proporção de concentrado para novilhas em terminação}

\author{
Pedro Leonardo de Paula Rezende ${ }^{1 *}$; João Restle ${ }^{2}$; Juliano José de Resende \\ Fernandes $^{2}$; Regis Luis Missio ${ }^{3}$; Ubirajara Oliveira Bilego ${ }^{4}$; \\ Tiago Pereira Guimarães 5
}

Highlights: The possible positive effects of replacing corn by soybean hulls, widely evaluated in recent studies, with diets of low to moderate inclusion of concentrate were not confirmed in the experimental conditions evaluated, with diets of high inclusion of concentrate for confined heifers.

\begin{abstract}
We examined the production performance of Nellore heifers fed high-concentrate $(90 \%)$ diets in which ground corn $(\mathrm{GC})$ was substituted by ground soybean hulls $(\mathrm{SH})$ at increasing levels $(0,33,66$, and $100 \%)$, in the concentrate portion. A total of 144 heifers $(263.40 \pm 13.90 \mathrm{~kg}$ average initial weight; 27 months old) received the test diets in a feedlot for 112 days. The experiment was set up as a completely randomised design with four treatments. Data were subjected to ANOVA and orthogonal contrasts, adopting $\alpha=5 \%$. The sum of squares of treatments in the contrast analysis was decomposed into two orthogonal contrasts (L - linear and Q - quadratic effect) for the level of SH substituting GC. Dry matter intake was not changed by the GC substitution levels, averaging $2.51 \%$ of body weight. There was a linear increase in neutral detergent fibre intake $(1.08,2.03,2.92,3.78,4.85 \mathrm{~kg} /$ day $)$ and feed conversion $(6.20,7.08,7.77$, and $8.67 \mathrm{~kg} / \mathrm{kg})$; and a linear decrease in total digestible nutrient intake $(5.78,5.16$, $5.03,5.12$, and $3.66 \mathrm{~kg} /$ day), average daily gain $(1.24,1.11,1.02$, and $0.89 \mathrm{~kg} /$ day), and slaughter weight $(383.52,374.71,363.25$, and $366.27 \mathrm{~kg})$ as the substitution level was increased $(0,33,66$, and $100 \%$, respectively). Subcutaneous fat thickness and loin-eye area were not influenced $(P>0.05)$, averaging $5.30 \mathrm{~mm}$ and $53.09 \mathrm{~cm}^{2}$, respectively. Substituting ground corn by ground soybean hulls in high-concentrate diets determined a reduction in production performance of feedlot-finished Nellore heifers.
\end{abstract}

Key words: Starch. By-product. Carcass traits. Dry matter intake. Feed conversion. Marbling.

\section{Resumo}

Foi estudado o desempenho produtivo de novilhas Nelore alimentadas com dietas de alta proporção de concentrado $(90 \%)$ nas quais o milho moído (MM) foi substituído por casca de soja farelada (CS) em

\footnotetext{
1 Presidente, Agência Goiana de Assistência Técnica, Extensão Rural e Pesquisa Agropecuária, EMATER, Goiânia, GO, Brasil. E-mail: pedrozootec@hotmail.com

2 Profs. Drs., Departamento de Zootecnia, Universidade Federal de Goiás, UFG, Goiânia, GO, Brasil. E-mail: jorestle@terra.com. br; juliano@vet.ufg.br

3 Prof. Dr., Departamento de Ciências Agrárias, Universidade Tecnológica Federal do Paraná, UTFPR, Pato Branco, PR, Brasil. E-mail: regisluismissio@gmail.com

4 Pesquisador Veterinário II, Instituto de Ciência e Tecnologia da COMIGO, Rio Verde, GO, Brasil. E-mail: birabilego@hotmail.com

5 Prof. Dr., Departamento de Zootecnia, Instituto Federal Goiano, Rio Verde, GO, Brasil. E-mail: tiagopereirarv@hotmail.com

* Author for correspondence
} 
níveis crescentes $(0,33,66$ e 100\%) da porção concentrada da dieta. Foram utilizadas 144 novilhas com $263,40 \pm 13,90 \mathrm{~kg}$ de peso inicial médio e 27 meses de idade alimentadas em confinamento durante 112 dias. O experimento foi instalado em delineamento inteiramente casualizado com quatro tratamentos. Os dados foram submetidos a ANOVA e contrastes ortogonais, adotando $\alpha=5 \%$. A soma dos quadrados dos tratamentos na análise de contraste foi decomposta em dois contrastes ortogonais [efeito L - linear e Q - quadrático] para o nível de substituição do milho por casca de soja. O consumo de matéria seca não foi alterado pelos níveis de substituição do GC por SH, apresentando média de 2,51\% do peso corporal. Houve aumento linear no consumo de fibra em detergente neutro $(1,08 ; 2,03 ; 2,92 ; 3,78 ; 4,85 \mathrm{~kg} / \mathrm{dia})$ e conversão alimentar $(6,20 ; 7,08 ; 7,77 ;$ e $8,67 \mathrm{~kg} / \mathrm{kg})$; e decréscimo linear na ingestão de nutrientes digestíveis totais $(5,78 ; 5,16 ; 5,03 ; 5,12$ e $3,66 \mathrm{~kg} /$ dia $)$, ganho médio diário $(1,24 ; 1,11 ; 1,02$ e 0,89 $\mathrm{kg} /$ dia) e peso ao abate $(383,52 ; 374,71 ; 363,25$ e $366,27 \mathrm{~kg})$ à medida que o nível de substituição foi aumentado. A espessura da gordura subcutânea e a área do lombo não foram influenciadas, com média de $5,30 \mathrm{~mm}$ e $53,09 \mathrm{~cm}^{2}$, respectivamente. A substituição do milho moído por casca de soja moída em dietas de alto concentrado determinou redução no desempenho produtivo de novilhas Nelore terminadas em confinamento.

Palavras-chave: Amido. Co-produto. Características da carcaça. Consumo de matéria seca. Conversão alimentar. Marmoreio.

\section{Introduction}

Corn is the main source of energy used in the diet of feedlot-finished cattle. It represents the major share of costs for the concentrate portion of the diet, accounting for up to $45 \%$ of total feedlot expenses (Missio et al., 2009). The increasing worldwide demand for corn resulting from its inclusion in the diet of humans and other species mainly poultry and swine -and recently, in biofuel production (Wallington et al., 2012), has prompted a rise in its price. As a consequence, its use has been restricted in the finishing of feedlot cattle fed highconcentrate diets.

In addition to the economic aspect, the nutritional characteristics of ground corn may also limit its inclusion in high-concentrate diets, since higher proportions of high-starch cereals may increase volatile fatty acid production in the rumen as well as direct the rumen metabolism towards the generation of more reduced products such as lactate. This, in turn, leads to a rapid rumen $\mathrm{pH}$ decline, reducing fibre digestion and feed efficiency, and ultimately raising production costs (Missio et al., 2009).

Economic losses may also arise due to occurrence of acute acidosis and animal death (Berchielli, Pires, \& Oliveira, 2011). Thus, alternative energy sources to ground corn may be used to decrease feeding costs while improving the nutritional properties of high-concentrate diets for feedlot cattle. In this regard, soybean hulls have been investigated as a substitute for corn by virtue of the similar production performance they provide when added to low- to medium-concentrate diets for confined cattle (Mueller, Blalock, \& Pritchard, 2011).

The favourable outcomes obtained with the use of soybean hulls in cattle diets have been attributed to increased digestibility of the dietary fibrous fraction resulting from improvements in the rumen environment, which in turn are provided by the low starch content in soybean hulls. This 'compensates' for the lower energy content of this ingredient compared to ground corn. However, most studies supporting this hypothesis investigated the substitution of corn by soybean hulls in low- to medium-concentrate diets (Mueller et al., 2011; Mueller \& Boggs, 2011; Cardoso et al., 2013; Freitas et al., 2013) and thus, the potential of this feedstuff in high-concentrate diets is still poorly understood. This is especially true for female cattle, which constituted $46.6 \%$ of the total cattle slaughtered in the first quarter of 2018 in Brazil (Instituto Brasileiro de Geografia e Estatísticas [IBGE], 2018). 
On this basis, the present study proposes examining the production performance and carcass and meat characteristics of feedlot-finished Nellore heifers fed high-concentrate diets in which ground corn was replaced by ground soybean hulls at different levels.

\section{Materials and Methods}

Heifers were fed high-concentrate $(90 \%)$ diets in which ground corn (Zea Mays) (GC) was replaced by ground soybean hulls (Glicine Max) (SH), at levels of $0,33,66$, and $100 \%$, to evaluate production performance. Corn silage (10\%) was used as the only roughage source. The experiment was carried out in the facilities of the Beef Cattle Section at the Technological Centre of the Agro-industrial Cooperative of Rural Producers of Southwest Goiás (COMIGO), located in Rio Verde - GO, Brazil (1 $7^{\circ}$ 46' 13.50" S, 51 02' 08.23" W; 815 m altitude). A total of 144 Nellore heifers $(263.4 \pm 13.9 \mathrm{~kg}$ average initial weight; 27 months old) were used. The heifers were confined in 16 gravel-floored $(5 \%$ slope) collective stalls $(10.00 \times 7.70 \mathrm{~m})$ equipped with automatic drinkers and concrete feed troughs. All experimental procedures were approved by the Ethics Committee on Animal Experimentation at the Federal University of Goiás (approval no. 076/2015).
Samples of feed and orts were collected weekly, pre-dried in a forced-air oven at $55{ }^{\circ} \mathrm{C}$ for $72 \mathrm{~h}$, ground through a Wiley mill (5-mm particle size), homogenised, and stored for chemical analysis of ingredients (Table 1) and diets (Table 2). The concentrations of dry matter (DM), mineral matter (MM), ether extract (EE), and crude protein (CP) were determined as proposed by the Association of Official Analytical [AOAC] (2002). Neutral detergent fibre (NDF) and acid detergent fibre (ADF) levels were determined in accordance with Van Soest, Robertson and Lewis (1991), and Van Soest (1973), respectively. Total carbohydrates (TC) and non-fibrous carbohydrates (NFC) were calculated as recommended by Sniffen, O'Connor, Van Soest, Fox, \& Russell, (1992), as follows: TC $=100-(\mathrm{CP}$ $+\mathrm{EE}+\mathrm{MM})$ and $\mathrm{NFC}=\mathrm{TC}-\mathrm{NDF}$. The in vitro DM digestibility of the diets was determined using samples collected immediately after supply and homogenising the roughage with the concentrate in the troughs, following the methodology proposed by Tilley and Terry (1963). The total digestible nutrient (TDN) content of the diets was estimated from the in vitro digestibility values of the nutrients, using equations described by the National Research Council [NRC] (1996).

Table 1

Chemical composition and proportion of ingredients used in the diets

\begin{tabular}{lccccccccc}
\hline \multirow{2}{*}{ Variable } & \multicolumn{4}{c}{ Nutrient,\% DM } & \multicolumn{4}{c}{ Ingredient,\% DM } \\
\cline { 2 - 10 } & CP & NDF & ADF & EE & DM & $0^{1}$ & $33^{2}$ & $66^{3}$ & $100^{4}$ \\
\hline Corn silage & 7.86 & 51.20 & 33.10 & 3.24 & 36.60 & 10.00 & 10.00 & 10.00 & 10.00 \\
Ground corn & 8.34 & 4.06 & 3.33 & 3.55 & 87.20 & 64.10 & 44.01 & 22.70 & -- \\
Soybean hulls & 12.70 & 69.60 & 42.30 & 2.34 & 91.00 & -- & 21.89 & 43.78 & 66.90 \\
Soybean meal & 46.40 & 9.12 & 6.04 & 3.87 & 90.50 & 23.90 & 22.10 & 21.53 & 21.10 \\
Mineral mixture* & 0.00 & 0.00 & 0.00 & 0.00 & 96.00 & 2.00 & 2.00 & 2.00 & 2.00 \\
\hline
\end{tabular}

Dry matter (DM); neutral detergent fibre (NDF); acid detergent fibre (ADF); crude protein (CP); ether extract (EE); ${ }^{1}-100 \%$ corn; ${ }^{2}-33 \%$ of corn substituted by soybean hulls; ${ }^{3}-66 \%$ of corn substituted by soybean hulls; ${ }^{4}-100 \%$ soybean hulls; * ${ }^{*}$ phosphate $13.56 \%$; calcite $50.53 \%$; micro-mineral mixture $9.86 \%$; white salt $24.65 \%$; virginiamycin $0.81 \%$; ionophore $0.59 \%$. 


\section{Table 2}

\section{Chemical composition of experimental diets}

\begin{tabular}{lcccc}
\hline \multirow{2}{*}{ Item (\% of dry matter) } & \multicolumn{4}{c}{ Substitution level of corn by soybean hulls, \% } \\
\cline { 2 - 5 } & 0 & 33 & 66 & 100 \\
\hline Dry matter \% of fresh matter & 80.84 & 81.48 & 82.13 & 82.82 \\
Mineral matter & 5.43 & 4.78 & 5.96 & 6.27 \\
Crude protein & 17.03 & 17.30 & 18.04 & 18.89 \\
Ether extract & 2.94 & 2.75 & 2.55 & 2.33 \\
Neutral detergent fibre & 14.02 & 25.41 & 36.83 & 48.90 \\
Acid detergent fibre & 7.35 & 14.81 & 22.33 & 30.28 \\
Non-fibrous carbohydrates & 60.59 & 49.76 & 36.62 & 23.60 \\
Total carbohydrates & 74.60 & 75.16 & 73.45 & 72.51 \\
Total digestible nutrients & 75.70 & 73.20 & 70.70 & 68.30 \\
In vitro dry matter digestibility & 75.70 & 73.20 & 70.70 & 68.30 \\
\hline
\end{tabular}

*Estimated.

The diets (Table 1) were formulated aiming at protein equivalence. To reduce the effects of the great variation in nutritional contents (protein, mainly) in the soybean hulls (Mielenz, Bardsley, \& Wyman, 2009; Rojas, Siqueira, Miranda, Tardioli, \& Giordano, 2014), all experimental diets were formulated so as to exceed the metabolisable protein level recommended by the NRC (1996) for a daily weight gain of $1.2 \mathrm{~kg}$, considering a dry matter intake of $2.4 \%$ body weight (BW). This protein level $(17.8 \%)$ was defined to ensure that animal performance would not be limited by small variations in the protein content of the diets caused by variations in the concentrations of this nutrient in $\mathrm{SH}$. The diet was supplied at $08 \mathrm{~h} 00$ and $17 \mathrm{~h} 00$, in a $10 \%$ higher quantity than the daily voluntary intake.

At the start of the feedlot period (112 days), the heifers were subjected to parasitic control and acclimated to the diets and facilities for 14 days. The animals were weighed individually at the start of the experimental period and every 21 days, after being fasted for 12-14 h. Total weight gain (TWG, $\mathrm{kg}$ ) was determined by subtracting the final weight (FW, kg) from the initial weight (IW, kg). Average daily weight gain (ADG, $\mathrm{kg}$ /day) was calculated as the difference between FW and IW divided by the number of days in the experimental period (98). The daily intakes of DM (DMI, $\mathrm{kg}$ /day) and nutrients were calculated by subtracting the orts from the previous day from the amount of feed supplied. Feed conversion ( $\mathrm{FC}, \mathrm{kg} / \mathrm{kg}$ ) was calculated as ADG/DMI. The animals were assessed subjectively for body condition score (BCS, points) by a trained evaluator who determined it on a scale of one (too lean) to five (too fat) as described by Restle (1977).

The following body measurements were taken at the start and end of the experimental period: height at withers and rump (distance from the soil surface to the withers and sacrum, respectively); heart girth (circumference measured from the caudal region to the scapula, passing along the sternum and spinous processes of the thoracic vertebrae), and body length (distance between the scapulohumeral joint and the coxal iliac tuberosity), which was taken using a tape measure lateral to the animal's body as described by Rezende et al. (2011).

Slaughter weight (SW) was obtained using a digital scale after a fasting period of 12-14 h, immediately before the animals were loaded onto the truck to a slaughterhouse under the Federal Inspection Service (Serviço de Inspeção Federal 
- SIF) in the city of Palmeiras, Goiás, Brazil. Hot carcass weight (HCW) was measured at the end of the slaughter line, immediately after bleeding, removal of hide, head, feet, and tail, evisceration, and cleaning of the carcasses. Cold carcass weight (CCW) was measured using a digital scale after the carcasses were chilled for $24 \mathrm{~h}$ in a cold room at 0 $\pm 3{ }^{\circ} \mathrm{C}$. Hot carcass yield (HCY) was calculated by dividing HCW by SW and multiplying the result by 100 .

After the carcasses were chilled for $24 \mathrm{~h}$, the following measurements were performed on the right half: carcass length (using a tape measure from the cranial border, in the middle portion of the first rib, to the cranial border of the pubic bone); leg length (measured from the pubic bone to the tibiotarsal joint); thigh thickness (measured with a compass, with one end fixed at the outermost part of the topside and the other at the outermost part of the leg); arm length (obtained using a tape measure from the tuberosity of the olecranon to the distal end of the humerus); and arm circumference (measured in the middle portion of the humerus, involving the muscles that surround it).

To determine the weight and percentage of primal cuts (pistola hindquarter, forequarter, and short ribs), these were extracted from the right half of the carcass after the carcasses were chilled at 0 $\pm 3{ }^{\circ} \mathrm{C}$, and their percentage was calculated relative to cold carcass weight (CCW). The hindquarter cut comprised the rear region of the carcass, which was separated from the forequarter between the fifth and sixth ribs, at approximately $22 \mathrm{~cm}$ from the spine. The forequarter cut included neck, shoulder, arm, and five ribs. Short ribs included six ribs, which were separated at approximately $22 \mathrm{~cm}$ from the spine, and the abdominal muscles as described by Rezende et al. (2013).

To estimate muscle expression in the carcass, with an emphasis on the hindquarter, carcass conformation was determined by a trained evaluator on the right half of the carcass after chilling for
$24 \mathrm{~h}$. This variable was assessed subjectively, in accordance with the methodology described by Müller (1987). By this method, scores of 1-18 points were assigned ( 1 to $3=$ inferior; 4 to $6=$ poor; 7 to $9=$ fair; 10 to $12=$ good; 13 to $15=$ very good; 16 to 18 = superior). Carcass compactness was determined as the ratio between $\mathrm{CCW}(\mathrm{kg})$ and carcass length $(\mathrm{cm})$.

Subcutaneous fat thickness (SFT) was measured at three points of the Longissimus dorsi muscle, at the 12th rib on the left half of the carcass, using a digital calliper. Values were expressed in $\mathrm{mm}$ and in $\mathrm{mm} / \mathrm{kg}$ of cold carcass, after the arithmetic mean of the three measurements was calculated. Loin-eye area (LEA) was measured by making a transverse section between the 12th and 13th ribs in the Longissimus dorsi muscle on the left half of the carcass and outlining the muscle on tracing paper. Subsequently, the image area was determined using AUTOCAD ${ }^{\circledR}$ software, with values expressed in $\mathrm{cm}^{2}$ and $\mathrm{cm}^{2} / \mathrm{kg}$ of cold carcass. Marbling fat in the meat was determined on the exposed face of the transverse section of the Longissimus dorsi muscle at the 12th rib on the left half of the carcass after chilling for $24 \mathrm{~h}$, by a subjective assessment of quantity and size of intramuscular fat granules. Scores of 1-18 were assigned for this trait (1 to 3 $=$ traces; 4 to $6=$ slight; 7 to $9=$ little; 10 to $12=$ medium; 13 to $15=$ moderate; 16 to $18=$ abundant) (Müller, 1987).

The experiment was set up as a completely randomised design with four treatments (diets). Data were subjected to analysis of normality and homogeneity of variances, and once these assumptions were met, they were subjected to ANOVA and orthogonal contrasts, adopting $\alpha=5 \%$. The sum of squares of treatments in the contrast analysis was decomposed into two orthogonal contrasts ( $\mathrm{L}$ - linear effect $\left(\begin{array}{llll}0 & -1 & 0 & 1\end{array}\right)$ and

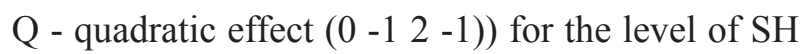
substituting GC in the concentrate portion of the diet. The following mathematical model was used: 
$\gamma_{i}=\mu+\beta_{i}+\varepsilon_{i}$, where $\gamma_{i}=$ dependent variable; $\mu=$ overall mean; $\beta_{\mathrm{i}}=$ treatment effect of order i $(0,33$, 66 , and $100 \%$ of GC substituted by $\mathrm{SH})$; and $\varepsilon_{\mathrm{i}}=$ residual experimental error.

\section{Results and Discussion}

Dry matter intake (DMI) was not changed (P $>0.05)$ by the levels of $\mathrm{SH}$ replacing $\mathrm{GC}$ in the concentrate portion of the diet (Table 3 ) in any of the forms this variable was expressed, averaging
$7.83 \mathrm{~kg} / \mathrm{day}, 2.51 \% \mathrm{BW}$, and $1.86 \mathrm{~g} / \mathrm{kg}$ of metabolic weight (MW). These results are in line with most findings reported in the literature (Cardoso et al., 2013; Mueller et al., 2011; Freitas et al., 2013) but disagree with some in which DMI declined (Ranathunga, Kalscheur, Hippen, \& Schingoethe, 2010; Mohammadzadeh, Rezayazdi, \& Nikkhah, 2014) or increased (Mueller et al., 2011) as the starch from corn was substituted by the digestible fibre from $\mathrm{SH}$ in ruminant diets.

\section{Table 3}

Means and standard errors of the intakes of dry matter (DM), crude protein (CP), ether extract (EE), neutral detergent fibre (NDF), non-fibrous carbohydrates (NFC), and total digestible nutrients (TDN) of experimental diets for heifers fed diets containing substitution levels of corn by soybean hulls

\begin{tabular}{|c|c|c|c|c|c|c|c|}
\hline \multirow{2}{*}{ Intake } & \multicolumn{4}{|c|}{ Substitution level of corn by soybean hulls, $\%$} & \multirow{2}{*}{ SEM } & \multicolumn{2}{|c|}{$P$ value ${ }^{4}$} \\
\hline & 0 & 33 & 66 & 100 & & $\mathrm{~L}$ & Q \\
\hline $\mathrm{DM}^{1}$ & 7.69 & 8.00 & 7.93 & 7.72 & 0.172 & 0.968 & 0.129 \\
\hline $\mathrm{DM}^{2}$ & 2.41 & 2.53 & 2.56 & 2.55 & 0.013 & 0.126 & 0.296 \\
\hline $\mathrm{DM}^{3}$ & 1.82 & 1.90 & 1.89 & 1.85 & 0.006 & 0.667 & 0.132 \\
\hline $\mathrm{CP}^{1}$ & 1.31 & 1.38 & 1.43 & 1.46 & 0.033 & 0.002 & 0.484 \\
\hline $\mathrm{CP}^{2}$ & 0.41 & 0.44 & 0.46 & 0.48 & 0.003 & $<0.001$ & 0.635 \\
\hline $\mathrm{CP}^{3}$ & 0.31 & 0.32 & 0.34 & 0.35 & 0.001 & $<0.001$ & 0.423 \\
\hline $\mathrm{NDF}^{1}$ & 1.08 & 2.03 & 2.92 & 3.78 & 0.141 & $<0.001$ & 0.306 \\
\hline $\mathrm{NDF}^{2}$ & 0.34 & 0.64 & 0.94 & 1.12 & 0.021 & $<0.001$ & 0.264 \\
\hline $\mathrm{NDF}^{3}$ & 0.25 & 0.48 & 0.69 & 0.91 & 0.019 & $<0.001$ & 0.313 \\
\hline $\mathrm{NFC}^{1}$ & 4.65 & 3.98 & 2.91 & 1.82 & 0.182 & $<0.001$ & 0.154 \\
\hline $\mathrm{NFC}^{2}$ & 1.45 & 1.26 & 0.93 & 0.60 & 0.023 & $<0.001$ & 0.099 \\
\hline $\mathrm{NFC}^{3}$ & 1.10 & 0.94 & 0.69 & 0.44 & 0.024 & $<0.001$ & 0.055 \\
\hline $\mathrm{TDN}^{1}$ & 5.78 & 5.16 & 5.03 & 5.12 & 0.121 & 0.001 & 0.052 \\
\hline $\mathrm{TDN}^{2}$ & 1.64 & 1.49 & 1.49 & 1.56 & 0.016 & 0.232 & 0.055 \\
\hline $\mathrm{TDN}^{3}$ & 71.12 & 64.30 & 63.93 & 66.58 & 0.005 & 0.039 & 0.089 \\
\hline
\end{tabular}

${ }^{1} \mathrm{~kg} / \mathrm{day} ;{ }^{2} \%$ of body weight $(\mathrm{BW}) ;{ }^{3} \mathrm{~g} / \mathrm{kg}$ of metabolic weight $(\mathrm{MW}) ;{ }^{4}$ - Probability for the orthogonal contrasts: L - linear $(0-101)$ and Q - quadratic ( 0 - 12 - 1$)$ effects of $\mathrm{SH}$ inclusion as a substitute for $\mathrm{GC} ; \mathrm{CP}, \mathrm{kg} /$ day $=1.32+0.0015 \mathrm{SH}, \mathrm{R}^{2}=0.52 ; \mathrm{CP}, \% \mathrm{BW}=$ $0.412+0.00071 \mathrm{SH}, \mathrm{R}^{2}=0.63 ; \mathrm{CP}, \mathrm{g} / \mathrm{kg} \mathrm{MW}=0.31+0.00041 \mathrm{SH}, \mathrm{R}^{2}=0.61 ; \mathrm{NDF}, \mathrm{kg} / \mathrm{day}=1.11+0.027 \mathrm{SH}, \mathrm{R}^{2}=0.99 ; \mathrm{NDF}, \%$ $\mathrm{BW}=0.365+0.0008 \mathrm{SH} ; \mathrm{R}^{2}=0.88 ; \mathrm{NDF}, \mathrm{g} / \mathrm{kg} \mathrm{MW}=0.261+0.0065 \mathrm{SH} ; \mathrm{R}^{2}=0.99 ; \mathrm{TDN}, \mathrm{kg} / \mathrm{day}=5.67-0.0011 \mathrm{SH} ; \mathrm{R}^{2}=0.57 ;$ $\mathrm{TDN}, \mathrm{g} / \mathrm{kg} \mathrm{MW}=71.14-0.036 \mathrm{SH}+0.00046 \mathrm{SH} ; \mathrm{R}^{2}=0.42 ; \mathrm{SEM}=$ standard error of the mean. 
According to Ipharraguerre and Clark (2003), the varying results in research on the use of $\mathrm{SH}$ in ruminant diets may be attributed to the proportion of concentrate used in the diet; inclusion level or physical form of the SH used; type of carbohydrate to be substituted; type and physical form of forage used; and incidence of positive or negative association effects occurring before or after $\mathrm{SH}$ addition to the diet. The decreasing DMI observed in ruminants fed $\mathrm{SH}$ has been attributed to physical limitation of the reticulorumen caused by the increased NDF content in the diets, which was confirmed in experiments in which the proportion of roughage exceeded that of concentrate (Ranathunga et al., 2010; Bittner et al., 2016). By contrast, increases in DMI have been associated with the animal's attempt to elevate its feed intake in order to maintain its energy intake level, given the reduced energy content of diets in which GC was substituted by $\mathrm{SH}$ or other by-products. The present results are similar to those obtained by Cardoso et al. (2013), who partially substituted corn with alternative energy sources (millet, sorghum, or soybean hulls) in concentrate supplements for beef cattle and found no differences in total DMI, pasture DMI, or in the intake of other nutrients.

The intakes of $\mathrm{CP}$ and NDF rose linearly $(\mathrm{P}<$ 0.05 ) with the $\mathrm{SH}$ levels (Table 3 ), likely because of the higher concentrations of those dietary fractions in $\mathrm{SH}$. Conflicting results regarding $\mathrm{CP}$ intake may in part be due to great variations in nutritional contents - especially the protein in $\mathrm{SH}$ - which is a consequence of an efficient industrialisation process and of the amount of residual soybean meal present in this by-product (Mielenz et al., 2009). This may lead to variable amounts of protein (11-15\%), as demonstrated by Rojas et al. (2014). The diets were formulated aiming at protein equivalence; however, chemical analysis (Table 2) showed that those containing higher proportions of SH had more crude protein, which is possibly due to the great variation in protein content in that ingredient. To some extent, the current results are in line with other studies (Ludden, Cecava, \& Hendrix, 1995; Alcalde et al., 2009) in which the authors found increased NDF intake but no significant changes for $\mathrm{CP}$ intake when corn was substituted by SH. In the present work, the amount of SH used in the treatment in which GC was entirely replaced with $\mathrm{SH}$ was higher than that used in the above-mentioned studies $(66.9 \%)$, where CP intake did not differ, which may explain the diverging results.

The intakes of NFC and TDN decreased linearly $(\mathrm{P}<0.05)$ as the level of SH replacing GC was increased (Table 3), which is a consequence of the lower concentration of those components in $\mathrm{SH}$ (Table 2). Average daily gain decreased linearly $(\mathrm{P}<0.05)$ as the $\mathrm{SH}$ levels were elevated. As a consequence, total weight gain (TWG) showed similar variations (Table 4). These results are due mainly to TDN intake, which decreased as the amount of $\mathrm{SH}$ in the diets was increased. This hypothesis was raised by Ludden et al. (1995), who showed that soybean hulls contain $74-80 \%$ of the energy value of corn when included in $90 \%$ concentrate diets supplied to feedlot steers, causing a linear reduction in ADG. Other studies (Freitas et al., 2013; Mueller et al., 2011) proposed that substituting $\mathrm{GC}$ by $\mathrm{SH}$ at low levels (up to $30 \%$ on a DM basis) did not cause significant changes in the weight gain of feedlot cattle due to the elevated passage rate of SH (Cannas et al., 2013). Coupled with the small particle size of SH (Ferreira et al., 2011; Gentil et al., 2011), this higher passage rate would allow for energy intakes similar to those provided by diets containing corn, as a result of increased DMI. In the current study, no such 'compensation' effect was observed, which is possibly due to the highest $\mathrm{SH}$ inclusion level that reached $66.9 \%$ of the DM in the treatment with maximum inclusion. 
Table 4

Means and standard errors of initial weight (IW), average daily weight gain (ADG), total weight gain (TWG), final body condition score (FBCS), feed conversion (FC), rump height (RH), height at the withers (HW), heart girth (HG), and body length (BL) of heifers fed diets containing substitution levels of corn by soybean hulls

\begin{tabular}{|c|c|c|c|c|c|c|c|}
\hline & \multicolumn{4}{|c|}{ Substitution level of corn by soybean hulls, $\%$} & \multirow{2}{*}{ SEM } & \multicolumn{2}{|c|}{$P$ value $^{1}$} \\
\hline & 0 & 33 & 66 & 100 & & $\mathrm{~L}$ & Q \\
\hline $\mathrm{IW},{ }^{\mathrm{kg}}$ & 262.92 & 262.86 & 266.09 & 264.53 & 1.44 & 0.680 & 0.861 \\
\hline $\mathrm{ADG},{ }^{\mathrm{kg} / \mathrm{day}}$ & 1.24 & 1.13 & 1.02 & 0.89 & 0.02 & $<0.001$ & 0.389 \\
\hline TWG, $\mathrm{kg}$ & 120.28 & 109.61 & 97.97 & 86.33 & 2.53 & $<0.001$ & 0.380 \\
\hline FBCS, points & 3.44 & 3.50 & 3.58 & 3.52 & 0.01 & 0.669 & 0.394 \\
\hline $\mathrm{FC}, \mathrm{kg} / \mathrm{kg}$ & 6.20 & 7.08 & 7.77 & 8.67 & 0.17 & 0.035 & 0.016 \\
\hline $\mathrm{RH},{ }^{\mathrm{cm}}$ & 139.91 & 139.20 & 138.82 & 138.03 & 0.36 & 0.853 & 0.160 \\
\hline HW, ${ }^{\mathrm{cm}}$ & 132.32 & 133.86 & 135.46 & 132.86 & 0.33 & 0.453 & 0.057 \\
\hline $\mathrm{HG},{ }^{\mathrm{cm}}$ & 184.88 & 182.26 & 178.36 & 179.71 & 5.77 & 0.007 & 0.430 \\
\hline $\mathrm{BL},{ }^{\mathrm{cm}}$ & 105.27 & 102.88 & 102.29 & 99.16 & 0.79 & 0.007 & 0.539 \\
\hline
\end{tabular}

1 - Probability for the orthogonal contrasts: L - linear ( $\left.\begin{array}{llll}0 & -1 & 0 & 1\end{array}\right)$ and Q - quadratic ( 0 - $\left.12-1\right)$ effects of SH inclusion as a substitute for $\mathrm{GC}$; $\mathrm{ADG}=1.297-0.0052 \mathrm{SH}, \mathrm{R}^{2}=0.37$;WG $=125.891-0.508 \mathrm{SH}, \mathrm{R}^{2}=0.37 ; \mathrm{FC}=7.541+0.0244 \mathrm{SH}, \mathrm{R}^{2}=0.25 ; \mathrm{HG}=$ $184.52-0.093 \mathrm{SH}, \mathrm{R}^{2}=0.28 ; \mathrm{BL}=105.66-0.094 \mathrm{SH}, \mathrm{R}^{2}=0.28 ; \mathrm{SEM}=$ standard error of the mean.

Feed conversion rose linearly $(\mathrm{P}<0.05)$ with increasing proportions of SH replacing GC (Table 4), which is a reflection of the equivalence in DMI associated with a linear decrease in ADG. These results are similar to those described by Ludden, et al. (1995), who observed a reduction in feed efficiency as the dietary level of SH was increased. Bittner et al. (2016) examined the inclusion of SH at $0,12.5$, 25 , and $37.5 \%$ of DM in diets for feedlot-finished crossbred steers and found a linear decrease and a linear increase in weight gain and feed conversion, respectively, in response to the substitution of rolled corn by $\mathrm{SH}$. Those authors attributed those findings to the nutritional value of the diet, which reduced as the SH levels were elevated, considering that TDN declined from $88 \%$ to $82 \%$ when the inclusion level was increased from $12.5 \%$ to $37.5 \%$. Freitas et al. (2013), on the other hand, evaluated the inclusion of SH in low- to medium-concentrate diets for feedlot steers and did not find changes in feed conversion as the ingredient replaced corn in the diet. However, considering the hypothesis that the use of $\mathrm{SH}$ in ruminant feeding improves the digestion of the fibrous portion of the diet (Alcalde et al., 2009), better feed conversion can be expected when using $\mathrm{SH}$ to replace GC in diets with a higher proportion of roughage than concentrate. Nevertheless, Rezende et al. (2018) substituted 0, 25, 50, 75, or $100 \%$ of corn with $\mathrm{SH}$ in the finishing diet of Nellore steers and proved that replacing the starch from corn with the digestible fibre from $\mathrm{SH}$ does not improve rumen $\mathrm{pH}$ or increase DM intake and apparent digestibility. Those researchers used diets containing $90 \%$ concentrate and $10 \%$ sugarcane bagasse as the only roughage source.

Final body condition score (FBCS) was not changed $(\mathrm{P}>0.05)$ by the increasing levels of $\mathrm{SH}$ added to the diet (Table 4), averaging 3.51 points. This result conflicts with the NRC (1996), which states that increased weight gain means increased body fat deposition rates, in cattle. In the present experimental conditions, this hypothesis was not confirmed, since physiological maturity and feeding time in the feedlot are determining factors of body fat accumulation (Missio et al., 2013). Thus, it is believed that the weight gain variations within the 98-day experimental period were not sufficient 
to increase body fat deposition and consequently improve FBCS. Moreover, given the genetic group to which the animals belonged (Nellore), the physiological stage during which body fat deposition is thought to be intensified was not yet consolidated, as they were young animals (heifers).

Rump height $(\mathrm{RH})$ and height at the withers (HW) were not affected $(\mathrm{P}>0.05)$ by the substitution of GC by $\mathrm{SH}$, averaging 138.99 and $133.62 \mathrm{~cm}$, respectively (Table 4). Gomes et al. (2012) described similar results in an experiment investigating the inclusion of SH levels $(0,15,30$, and $45 \%$ ) replacing corn in calf diets. In their study, no alterations were found in $\mathrm{HW}$ or $\mathrm{RH}$, which reflects the similar ADG observed across treatments. The present results indicate that the animals had their bone growth already consolidated, considering that this tissue has its greatest growth spurt during young age (between birth and puberty), whereas muscle growth is intensified in an intermediate stage, and fat, in a further advanced development phase (Berg \& Butterfield, 1976). This hypothesis was confirmed through the heaty girth (HG) and body length (BL) measurements, which declined linearly $(\mathrm{P}<0.05)$ as the substitution level increased (Table 4). This is mostly due to the limited muscle and fat tissue deposition caused by the decreasing $\mathrm{ADG}$, which, in turn, was a consequence of the reduced availability of net growth energy resulting from the increasing presence of SH. These findings agree with those obtained by Rezende et al. (2013), who demonstrated that although the height measurements were not influenced, the CG and BL of growing steers receiving lower energy levels in the feedlot decreased.
Slaughter weight decreased linearly $(\mathrm{P}<0.05)$ as the levels of $\mathrm{SH}$ replacing $\mathrm{GC}$ in the diet were increased (Table 5). The animals that received concentrate containing GC as the sole energy source were $17.25 \mathrm{~kg}$ heavier than those fed the diets with maximum SH inclusion. According to the regression equation, a $0.317 \mathrm{~g}$ decrease in $\mathrm{SW}$ was estimated for every percentage unit of GC substituted by SH. However, HCW and HCY were not altered (P > 0.05 ) by the levels of SH substituting GC, averaging $203.52 \mathrm{~kg}$ and $54 \%$, respectively. This suggests that differences in SW may be due to some non-carcass component or to an increase in gastrointestinal content, even after the fasting period of $12 \mathrm{~h}$, which is possibly a consequence of the high passage rate of SH (Cannas et al., 2013) and faster digestive tract emptying. These results are in line with those described by Freitas et al. (2013), who evaluated the production performance of steers fed $\mathrm{GC}, \mathrm{SH}$, or wheat bran as carbohydrate sources in $60 \%$ concentrate diets and found no significant effects on HCY, which averaged $57.63 \%$. Our results disagree, however, with those published by Bittner et al. (2016), who found that HCW declined linearly as they increased the amount of SH in the diet of feedlot steers $(389.63,383.73,380.56$, and 365.59 $\mathrm{kg}$ for the levels of $0.0,12.5,25.0$, and $37.5 \%$ of rolled corn replaced with $\mathrm{SH})$. In their experiment, the carcass of the steers that received diets with the maximum $\mathrm{SH}$ level was $23.04 \mathrm{~kg}$ lighter than that of animals that did not consume SH. The authors attributed those results to the lower energy content of SH. These diverging results could be attributed, in part, to the lower level of inclusion of SH compared to that used in the present study $(66.9 \%)$. 
Table 5

Means and standard errors of quantitative and qualitative characteristics of carcass and meat of heifers fed diets containing substitution levels of corn by soybean hulls

\begin{tabular}{|c|c|c|c|c|c|c|c|}
\hline & \multicolumn{4}{|c|}{ Substitution level of corn by soybean hulls, $\%$} & \multirow{2}{*}{ SEM } & \multicolumn{2}{|c|}{$P$ value ${ }^{1}$} \\
\hline & 0 & 33 & 66 & 100 & & $\mathrm{~L}$ & Q \\
\hline SW, ${ }^{\mathrm{kg}}$ & 383.52 & 374.71 & 363.25 & 366.27 & 6.042 & $<0.001$ & 0.263 \\
\hline $\mathrm{HCW},{ }^{\mathrm{kg}}$ & 204.91 & 210.92 & 202.29 & 195.96 & 2.713 & 0.254 & 0.163 \\
\hline $\mathrm{CCW},{ }^{\mathrm{kg}}$ & 203.17 & 206.08 & 198.25 & 189.50 & 2.831 & 0.095 & 0.172 \\
\hline $\mathrm{HCY},{ }^{\mathrm{kg} / \mathrm{kg}}$ & 0.53 & 0.56 & 0.55 & 0.55 & 0.057 & 0.117 & 0.251 \\
\hline SFT, ${ }^{\mathrm{mm}}$ & 5.04 & 6.32 & 4.29 & 5.58 & 0.274 & 0.789 & 0.822 \\
\hline LEA, ${ }^{\mathrm{cm} 2}$ & 53.46 & 54.40 & 53.72 & 50.80 & 0.943 & 0.393 & 0.251 \\
\hline FQT, $\%$ & 36.03 & 36.20 & 36.95 & 36.90 & 0.14 & 0.123 & 0.512 \\
\hline $\mathrm{PH},{ }^{\%}$ & 51.83 & 52.00 & 51.90 & 51.70 & 0.29 & 0.152 & 0.321 \\
\hline $\mathrm{SR},{ }^{\%}$ & 12.14 & 11.80 & 11.15 & 11.40 & 0.21 & 0.155 & 0.386 \\
\hline $\mathrm{AL},{ }^{\mathrm{cm}}$ & 43.70 & 43.20 & 43.04 & 42.79 & 0.18 & 0.696 & 0.120 \\
\hline CONF, points & 9.50 & 9.25 & 8.92 & 9.0 & 0.151 & 0.195 & 0.769 \\
\hline $\mathrm{AC},{ }^{\mathrm{cm}}$ & 33.50 & 33.87 & 33.45 & 33.33 & 0.18 & 0.742 & 0.439 \\
\hline $\mathrm{LL},{ }^{\mathrm{cm}}$ & 71.33 & 72.08 & 71.54 & 72.87 & 0.38 & 0.219 & 0.631 \\
\hline $\mathrm{CL},{ }^{\mathrm{cm}}$ & 129.87 & 131.54 & 130.91 & 130.41 & 0.47 & 0.630 & 0.263 \\
\hline $\mathrm{TT},{ }^{\mathrm{cm}}$ & 25.33 & 24.91 & 24.04 & 24.70 & 0.26 & 0.259 & 0.451 \\
\hline COMP, ${ }^{\mathrm{cm} / \mathrm{kg}}$ & 1.56 & 1.57 & 1.51 & 1.45 & 0.02 & 0.030 & 0.194 \\
\hline MAR, points & 9.58 & 8.75 & 7.00 & 8.91 & 0.55 & 0.452 & 0.310 \\
\hline
\end{tabular}

Slaughter weight $(\mathrm{SW})=-6.321 \mathrm{SH}+387.74 ; \mathrm{R}^{2}=0.80$; hot carcass weight $(\mathrm{HCW})$; cold carcass weight $(\mathrm{CCW})$; hot carcass yield (HCY); subcutaneous fat thickness (SFT); loin-eye area (LEA); conformation (CONF); forequarter (FQT); pistola hindquarter $(\mathrm{PH})$; short ribs (SR); arm length (AL); arm circumference (AC); leg length (LL); carcass length (CL); thigh thickness (TT); compactness $(\mathrm{COMP})=1.583-0.000174 \mathrm{SH}\left(\mathrm{R}^{2}=0.14\right)$; MAR $=$ marbling: 1 to $3=$ traces; 4 to $6=$ slight; 7 to $9=$ little; 10 to 12 = medium; 13 to $15=$ moderate; 16 to $18=$ abundant, as described by Müller (1987); ${ }^{1}$ - Probability for the orthogonal contrasts:

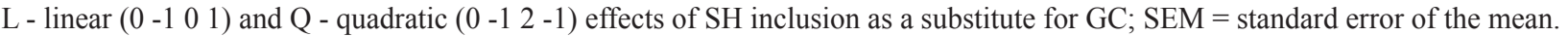

Subcutaneous fat thickness was not influenced $(\mathrm{P}>0.05)$ in any of the forms it was expressed (Table 5), averaging $5.3 \mathrm{~mm}$. This is considered a satisfactory value, as it meets the requirements set by Brazilian slaughterhouses. In Brazil, SFT values between 3-10 $\mathrm{mm}$ are desirable, considering that a minimum thickness of $3 \mathrm{~mm}$ is required for proper carcass chilling, without meat darkening or excessive muscle fibre shortening, which considerably compromise meat tenderness. The present results for SFT corroborate those presented by Bittner et al. (2016), who found that the level of substitution of rolled corn by SH in the finishing of feedlot steers had no effect on SFT measured at the 12th rib. Those authors obtained an average SFT of $3.09 \mathrm{~mm}$. Similarly, Freitas et al. (2013) did not detect significant effects of different energy sources on the SFT of steers, which averaged $3.1 \mathrm{~mm}$.

Loin-eye area measured in the Longissimus dorsi muscle was not influenced $(\mathrm{P}>0.05)$ in any of the forms it was expressed, averaging 53.08 $\mathrm{cm}^{2}$ (Table 5). The analysis of LEA is considered a representative measurement of the quantity, distribution, and quality of muscle mass (Hashimoto et al., 2007). Berg and Butterfield (1976) stated that no significant differences are expected for LEA in contemporary cattle sharing the same genetic composition when they are slaughtered at similar weights. This hypothesis would explain the present 
results, given the genetic homogeneity and the $\mathrm{CCW}$ across the animals. The current results agree with those described by Bittner et al. (2016), who found that the level of substitution of rolled corn by $\mathrm{SH}$ in finishing diets for feedlot steers had no effect on LEA, which averaged $83.68 \mathrm{~cm}^{2}$.

The yields of the primal cuts termed forequarter, pistola hindquarter, and short ribs were not influenced $(\mathrm{P}>0.05)$ by the $\mathrm{SH}$ inclusion levels, averaging $36.52,51.72$, and $11.55 \%$ of the $\mathrm{CCW}$, respectively (Table 5). These results corroborate the statement of Berg and Butterfield (1976) that, under normal animal rearing conditions, primal cuts in the carcass tend towards balance. On this basis, the similar carcass weights were likely the responsible factor for the equivalence observed in those cuts. Our findings are also in line with those described by Rezende et al. (2013), who found that feeding levels did not influence the weight or yield of primal cuts in feedlot crossbred heifers fed diets with different energy densities.

The objective carcass measurements were not changed $(\mathrm{P}>0.05)$. However, carcass compactness decreased linearly $(\mathrm{P}<0.05)$ as the levels of $\mathrm{SH}$ replacing GC in the diet were increased, which shows that tissue deposition efficiency worsened (Table 5). Compactness is a parameter of great importance in that it is directly proportional to tissue deposition per unit of carcass length, indicating carcass quality. Circumference measurements, in turn, are related to muscle expression in the carcass - in the current study, thigh thickness and arm circumference averaged 24.74 and $33.53 \mathrm{~cm}$, respectively. Arm, leg, and carcass lengths, which are linear measurements related to bone development, averaged 43.18, 71.95 , and $130.68 \mathrm{~cm}$, respectively. In view of the animal category investigated in the present study (growing cattle), the heifers exhibited similar bone and muscle growth. Furthermore, possible differences in availability of net growth energy provided by the diets were not sufficient to cause differences in linear carcass measurements within the experimental period. Carcass conformation was not influenced $(\mathrm{P}>0.05)$, averaging 9.16 points, which corresponds to the 'regular' classification (Table 5). Better conformed carcasses are preferred by slaughterhouses because they are associated with increased muscle hypertrophy and higher yields of secondary cuts at deboning. The current results corroborate those described by Rodrigues, Rossi, \& Moletta, (2008), who evaluated the carcass conformation of Holstein/Zebu crossbred steers using the same methodology and did not observe any effect of dietary energy levels on this parameter.

Marbling score was not influenced by the levels of SH substituting GC. This variable averaged 8.56 points, which is classified as 'little +' (Table 5). Bittner et al. (2016) found that SH inclusion in the diet as a substitute for rolled corn also did not have an effect on the marbling score of the meat of feedlot steers, although a linear downward trend $(p=0.07)$ was detected. According to Berg and Butterfield (1976), body fat deposition in cattle follows a chronological order throughout the animal's life, with intermuscular fat being the first adipose fraction to be deposited, followed by subcutaneous, and, lastly intramuscular (marbling) fat. Some authors (Di Marco, 1998; Vaz \& Restle, 2003) added that although marbling fat is the last body fat fraction to be deposited, it is the first to be mobilised under nutritional deficiency, which suggests that this parameter is determined by the nutritional history of the animal throughout its life, from embryonic phase to slaughter. Therefore, no differences were to be expected between the treatments since the animals originated from the same herd and were under the same nutritional management.

\section{Conclusions}

Substituting ground corn by ground soybean hulls as an alternative energy source in high-concentrate diets for feedlot heifers determined a reduction in the main production performance variables, notably weight gain, feed conversion, slaughter weight, and carcass compactness. 


\section{Acknowledgements}

The first author thanks the National Council for Scientific and Technological Development (CNPq) for the Doctoral fellowship grant. The last author thanks CNPq for the Research Productivity fellowship grant. The authors thank the Agroindustrial Cooperative of Rural Producers of Southwest Goiás (COMIGO) for the financial support and access to the physical structure for the development of field work.

\section{References}

Alcalde, C. R., Zambom, M. A., Passianoto, G. O., Lima, L. S., Zeoula, L. M., \& Hashimoto, J. H. (2009). Valor nutritivo de rações contendo casca do grão de soja em substituição ao milho moído para cabritos Saanen. Revista Brasileira de Zootecnia, 38(11), 2198-2203. doi: 10.1590/S1516-35982009001100019

Association of Official Analytical (2002). Chemists official methods of analysis. Gaithersburg, MD: Edited by William Horwitz.

Berchielli, T. T., Pires, A. V., \& Oliveira, S. G. de. O. (2011). Nutrição de ruminantes. Jaboticabal: Funep.

Berg, R. T., \& Butterfield, R. M. (1976). New concepts of cattle growth. New York: Sidney University.

Bittner, C. J., Nuttelman, B. L., Schneider, C. J., Burken, D. B., Johnson, L. J., Mader, T. L.,... Erickson, G. E. (2016). Effects of increasing soybean hulls in finishing diets with wet or modified distillers grains plus solubles on performance and carcass characteristics of beef steers. The Professional Animal Scientist, 32(6), 777-783. doi: 10.15232/ pas.2016-01507

Cannas, A., Cabiddu, A., Bomboi, G., Ligios, S., Floris, B., \& Molle, G. (2013). Decreasing dietary NFC concentration during mid-lactation of dairy ewes: does it result in higher milk production? Small Ruminant Research, 111(1-3), 41-49. doi: 10.1016/j. smallrumres.2012.09.009

Cardoso, A. B., Moraes, E. H. B. K., Oliveira, A. S., Zervoudakis, J. T., Cabral, L. S., Silva, P. I. J. L. R., \& Socreppa, L. M. (2013). Substituição parcial do milho por fontes energéticas para bovinos de corte em pastejo. Pesquisa Agropecuária Brasileira, 48(9), 1295-1302. doi: 10.1590/S0100-204X20130009000 14
Di Marco, O. N. (1998). Crescimento de vacunos para carne. Balcarce: Associación Argentina de Producción Animal.

Ferreira, E. M., Pires, A. V., Susin, I., Mendes, C. Q., Queiroz, M. A. A., Araujo, R. C.,... Loerch, S. C. (2011). Apparent digestibility, nitrogen balance, and ruminal constituents in ram lambs fed highconcentrate diets containing soybean hulls. Journal of Animal Science, 89(12), 4127-4133. doi: 10.2527/ jas.2010-3419

Freitas, L. da. S., Brondani, I. L., Segabinazzi, L. R., Restle, J., Alves, D. C., Fo., Pizzuti, L. A.,... Rodrigues, L. S. (2013). Performance of finishing steers fed different sources of carbohydrates. Revista Brasileira de Zootecnia, 42(5), 354-362. doi: 10.1590/S1516-35982013000500008

Gentil, R. S., Susin, I., Pires, A. V., Ferreira, E. M., Mendes, C. Q., Almeida, O. C., \& Queiroz, M. A. A. (2011). Metabolismo de nutrientes em ovinos alimentados com casca de soja em substituição ao feno de coastcross. Revista Brasileira de Zootecnia, 40(12), 2835-2843. doi: 10.1590/S151635982011001200030

Gomes, I. P. O, Neto, A. T., Medeiros, L. A., Orsolin, V., Neto, E. P., \& Semmelmann, C. E. N. (2012). Níveis de casca de soja em rações concentradas para bezerros de raças leiteiras. Archives of Veterinary Science, 17(2), 52-57. doi: 10.5380/avs.v17i2.16270

Hashimoto, J. H., Alcalde, C. R., Alcalde, C. R., Zambom, M. A., Silva, K. T. da., Macedo, F. A. F.,... Passionato, G. O. (2007). Desempenho e digestibilidade aparente em cabritos Boer x Saanen em confinamento recebendo rações com casca do grão de soja em substituição ao milho. Revista Brasileira de Zootecnia, 36(1), 174-182. doi: 10.1590/S1516-35982007000100021

Instituto Brasileiro de Geografia e Estatísticas (2018). Diretoria de pesquisas, coordenação de agropecuária, pesquisa da pecuária municipal e pesquisa trimestral do abate de animais 2018. Recuperado de http:// brasilemsintese.ibge.gov.br/ agropecuaria/efetivos-da-pecuaria.html

Ipharraguerre, I. R., \& Clark, J. H. (2003). Soyhulls as an alternative feed for lactating dairy cows: a review. Journal of Dairy Science, 86(4), 1052-1073. doi: $10.3168 /$ jds.S0022-0302(03)73689-3

Ludden, P. A., Cecava, M. J., \& Hendrix, K. S. (1995). The value of soybean hulls as a replacement for corn in beef cattle diets formulated with or without added fat. Journal of Animal Science, 73(9), 2706-2711. doi: $10.2527 / 1995.7392706 x$ 
Mielenz, J. R., Bardsley, J. S., \& Wyman, C. E. (2009). Fermentation of soybean hulls to ethanol while preserving protein value. Bioresource Technology, 100(14), 3532-3539. doi: 10.1016/j.biortech.2009. 02.044

Missio, R. L., Brondani, I. L., Freitas, L. da. S., Sachet, R. H., Silva, J. H. S., \& Restle, J. (2009). Desempenho e avaliação econômica da terminação de tourinhos em confinamento alimentados com diferentes níveis de concentrado na dieta. Revista Brasileira de Zootecnia, 38(7), 1309-1316. doi: 10. 1590/S151635982009000700021

Missio, R. L., Restle, J., Moletta, J. L., Kuss, F., Neiva, J. N. M, \& Moura, I. C. F. (2013). Características da carcaça de vacas de descarte abatidas com diferentes pesos. Revista Ciência Agronômica, 44(3), 644-651. doi: Recuperado de http://www.ccarevista.ufc.br/ seer/index.php/ccarevista/article/view/1879/845

Mohammadzadeh, H., Rezayazdi, K., \& Nikkhah, A. (2014). Effects of inclusion of graded amounts of soya bean hulls on feed intake, chewing activity and nutrient digestibility in dairy cows. Journal of Animal Physiology and Animal Nutrition, 98(3), 476-482. doi: 10.1111/jpn.12094

Mueller, C. J., \& Boggs, D. L. (2011). Use of soybean hulls with or without corn by-product protein sources in feedlot back grounding diets. The Professional Animal Scientist, 27(3), 228-234. doi: 10.15232/ S1080-7446(15)30478-2

Mueller, C. J., Blalock, H. M., \& Pritchard, R. H. (2011). Use of soybean hulls as a replacement for dry rolled corn in beef cattle feedlot receiving diets. Journal of Animal Science, 89(12), 4142-4150. doi: 10. 2527/ jas.2010-3653

Müller, L. (1987). Normas para avaliação de carcaças e concurso de carcaças de novilhos (2nd ed.). Santa Maria: Universidade Federal de Santa Maria.

National Research Council (1996). Nutrient requirement of beef cattle (7nd ed.). Washington: National Academy.

Ranathunga, S. D., Kalscheur, K. F., Hippen, A. R., \& Schingoethe, D. J. (2010). Replacement of starch from corn with nonforage fiber from distillers grains and soyhulls in diets of lactating dairy cows. Journal of Dairy Science, 93(3), 1086-1097. doi: 10.3168/ jds.2009-2332

Restle, J. (1977). Efeito da suplementação com energia e energia-proteína no ganho de peso e no comportamento reprodutivo de vacas. Revista $d a$
Faculdade de Agronomia da UFRGS, 1(2), 203-204.

Rezende, P. L. P., Restle, J., Bilego, U. O., Fernandes, J. J. R, Missio, L. R., Menezes, G. R., \& Guimarães, T. P. (2018). Digestibility and feeding behavior of cattle fed soybean hulls to replace corn in high concentrate diets. Semina: Ciências Agrárias, 39(1), 363-372. doi: 10.5433/1679-0359.2018v39n1p363

Rezende, P. L. P., Restle, J., Fernades, J. J. R., Pádua, J. T., Neto, M. D. F., \& Rocha, F. M. (2011). Performance and body development crossbred dairy cattle submitted to levels of supplementation in Brachiaria brizantha. Ciência Rural, 41(8), 14531458. doi: 10.1590/S0103-84782011005000097

Rezende, P. L. P., Restle, J., Padua, J. T., Fernandes, J. J. R., Lino, F. A., \& Guimarães, T. P. (2013). Carcass morphometry of crossbred steers subjected to different nutritional strategies in the growing and finishing phases. Acta Scientiarum. Animal Sciences, 35(2), 187-192. doi: 10.4025/actascianimsci.v3 $5 \mathrm{i} 2.17904$

Rodrigues, K., Rossi, P., Jr., \& Moletta, J. (2008). Avaliação das características de carcaça de bovinos mestiços Purunã, alimentados com diferentes níveis de energia na dieta. Archives of Veterinary Science, 13(4), 265-273. doi: 10.5380/avs.v13i4.15272

Rojas, M. J., Siqueira, P. F., Miranda, L. C., Tardioli, P. W., \& Giordano, R. L. C. (2014). Sequential proteolysis and cellulolytic hydrolysis of soybean hulls for oligopeptides and ethanol production. Industrial Crops and Products, 61, 202-210. doi: 10.1016/j.indcrop.2014.07.002

Sniffen, C. J., O’Connor, J. D., Van Soest, P. J., Fox, D. G., \& Russell, J. B. (1992). A net carbohydrate and protein system for evaluating cattle diets: II. Carbohydrate and protein availability. Journal of Animal Science, 70(11), 3562-3577. doi: $10.2527 / 1992.70113562 x$

Tilley, J. M., \& Terry, R. A. (1963). A two-stage technique for the in vitro digestion of forage crops. Journal British Grassland Society, 18(2), 104-111. doi: 10.1111/j.1365-2494.1963.tb00335.x

Van Soest, P. J. (1973). Collaborative study of aciddetergent fiber and lignin. Journal of the Association of Official Analytical Chemists, 56, 781-784.

Van Soest, P. J., Robertson, J. B., \& Lewis, B. A. (1991). Methods for dietary fiber, neutral detergent fiber, and nonstarch polyssacarides in relation to animal nutrition. Journal of Animal Science, 74(10), 35833597. doi: 10.3168/jds.S0022-0302(91)78551-2 
Vaz, F. N., \& Restle, J. (2003). Ganho de peso antes e após os sete meses no desenvolvimento e nas características de carcaça e da carne de novilhos Charolês abatidos aos dois anos. Revista Brasileira de Zootecnia, 32(3), 699-708. doi: 10.1590/S151635982003000300022
Wallington, T. A., Anderson, J. E., Mueller, S. A., Kolinski Morris, E., Winkler, S. L., Ginder, J. M., \& Nielsen, O. J. (2012). Corn ethanol production, food exports, and indirect land use change. Environmental Science \& Technology, 46(11), 6379-6384. doi: $10.1021 / \mathrm{es} 300233 \mathrm{~m}$ 